\title{
40 YEARS OF TOURISM STUDIES - A REMARKABLE STORY
}

\section{David Airey}

\section{University of Surrey}

\section{D.Airey@surrey.ac.uk}

\section{ABSTRACT}

The formal study of tourism as a distinct subject in the academy is about 40 years old, the same age as Tourism Recreation Research. Over these 40 years it has shown remarkable growth and development and in the process has changed and adapted. This article, drawing inter alia on the author's own 40 years in the tourism academy and on his writings over the period, plots the past, present and future of tourism studies. The article begins with the vocational origins and the rapid changes that brought tourism to a kind of maturity to take its place alongside other social sciences as a subject for research and teaching. It then explores the tensions and challenges that it has faced in more recent years as global competition has forced universities to focus more on their finances and reputations. In this environment, influenced by performance against various metrics, the position of tourism in the academy has been challenging. The article then turns to consider the current problems created by a metrics driven agenda and how there is an opportunity for tourism to meet the needs of a post-industrial world by focusing not on immediate metrics but on the characteristics that tourism offers as a complex area of study.

\section{KEYWORDS}

Vocational, maturity, multidisciplinary, funding, metrics, complexity 


\section{YEARS OF TOURISM STUDIES - A REMARKABLE STORY}

\section{INTRODUCTION}

The dates of Tourism Recreation Research match almost exactly those of tourism studies in higher education. Although Medlik (1965) identifies a few examples of tourism studies as early as the 1920s, the first tourism degree programmes as such were started at the end of the 1960s and early 1970s (Airey, 2005). Tourism Recreation Research was launched in the early 1970s. At that time there were no more than a handful of scholarly journals in tourism, in the UK there were two tourism degree programmes recruiting about 20 students a year, and there were about 160 million international tourist arrivals (United Nations World Tourism Organization, 2006). Forty years on we have more than 100 scholarly journals, there are 9,000 students enrolled on tourism degree programmes in the UK alone (Walmsley, 2012) and in China, where the first degree programme was introduced in 1978, by 2010 there were nearly 1,000 such programmes with half a million students (Xiao, 2000, Yang and Song, 2011). In 2012 international tourist arrivals topped one billion. In brief the story so far has been one of massive and almost continuous growth. But behind this growth there has also been significant change and more recently, at least for tourism education, a fair degree of uncertainty and tension. On the fortieth anniversary of Tourism Recreation Research, this article aims both to chart some of the changes in tourism studies and to explore the current uncertainties and tensions. It is in part a celebration of success but it also serves as a reminder of challenges past, present and future.

The timing of this article also coincides with another fortieth anniversary; that of the author's 40 years since joining the tourism academy. It therefore also provides an opportunity for reflection on a more personal level. For this reason the tracking of the development of tourism studies here draws heavily on the author's own research and writings over the period. To that extent it has both a personal and a geographical bias. But notwithstanding this bias, it is hoped that the underlying messages also have a broader resonance, which will find echoes in other contexts. The approach is to deal with the 
development under three headings, past, present and future, and for each, drawing substantially on the author's work but supplemented by the literature produced by others, to identify, explain, comment on and, where appropriate, to speculate about the remarkable development of tourism in the academy.

\section{THE STORY SO FAR}

The numbers given above, both for the growth in scholarly journals and for enrolments on degree programmes, provide the essence of the story so far. To these we can add a range of other metrics which suggest that tourism has become an established part of the academic repertoire. There are now thousands of books published about tourism. PhD completions related to tourism have rocketed, increasing in the UK more than 8-fold between 1990 and 2002 (Botterill and Gale, 2005). Tourism scholarship is now supported by a range of organisations and networks from, for example, national bodies such as in the Association for Tourism in Higher Education in the UK and the Council for Australasian University Tourism and Hospitality Education (CAUTHE), while internationally, bodies such as ATLAS, The Travel and Tourism Research Association, The International Association for Experts in Scientific Tourism, and the International Academy for the Study of Tourism provide opportunities for scholars to meet and exchange ideas. In the meantime even the UN World Tourism Organization with its Knowledge Network and its TEDQUAL mechanism for quality assurance recognises the significance of tourism education.

Of course, these developments have not happened by accident or in insolation. Apart from the remarkable growth in tourism itself, three other changes provide the context for the emergence of tourism in the academic repertoire. First there was a remarkable growth in higher education itself fostered in part by the recognition of the link between an educated workforce and economic prosperity (Airey, 2005). In Australia, for example, in the thirty years after 1970, higher education student numbers increased seven-fold from 160,000 in 1970 to over 1.2 million in 2011 (Department 
of Education, Training and Youth Affairs 2001, Department of Industry, Innovation, Science, Research and Tertiary Education 2012). Ayikoru, Tribe and Airey (2009) draw attention to the extent to which this expansion of the higher education system was driven by the need for an educated workforce and a neoliberal agenda. Secondly, taking a less traditional approach to the programmes of study that they were prepared to offer, new universities created during this period of growth in higher education, recognised in tourism an area of study that would attract students and would foster links with a growing economic sector and what is more the programmes could be offered at a reasonably low cost (Airey, 1995). This is very much reflected in the aims of the programmes which clearly reveal tourism's vocational origins. As Airey and Johnson (1999), note "Career Opportunities" and "Employment/Employers Links/Work" were the top aims of tourism programmes as presented in the course catalogues. The third change relates to the overall provision for, and funding of, higher education. In short, universities were achieving much greater freedoms to determine their own course offerings in a competitive market place and indeed were encouraged to compete (Airey, 1995). The outcome, especially for the new universities, was a search for programmes that would attract students. Tourism attracted their attention.

By 1979 Airey (1979) had identified 20 programmes in the UK and was commenting on the "speed" and "diversity" of the developments. By 1993 some authorities were suggesting that tourism education had "come of age". For example in its review of Tourism Studies Degree Courses the Council for National Academic Awards in the UK (1993) commented: "Reflecting the economic and social significance of tourism, as well as its growing literature, the study of the subject has arguably come-of age". This was a theme that was picked up again some years later by Jafari (2001) who tracked tourism development through a series of platforms, and then by Airey (2008b) in a consideration of the case for tourism as a mature area of study in the academy. He suggested that the period of immaturity, dominated above all by debates about the curriculum and its content, had by then been brought to a close, partly influenced by Tribe's analysis of the curriculum space (Tribe, 
2002) which pointed to the philosophic as well as the action content of tourism programmes, and partly by initiatives such as that by the Quality Assurance Agency in the UK (2000) to reach a broadly agreed content for tourism programmes of study in higher education. This debate about the curriculum and its content and how this fitted in with the perceived needs of industry and for careers in tourism, had indeed dominated the first period of development (Airey and Nightingale, 1981). Tribe (2005) confirms this preoccupation in identifying that between 1974 and 2001, of the 301 papers he noted as belonging to tourism education, some $86 \%$ focused on the curriculum.

Pursuing the theme of maturity Airey (2008b) identified enquiries into teaching (Stergiou et al., 2008), the cultural turn in tourism (Aitchison, 2006, Ateljevic et al., 2007) and growing self-critical awareness (Tribe, 2006b) as pointers to the growing maturity of the subject. Drawing on evidence from commentators (Airey, 2008a) on the "nature and growth of knowledge [....] the development of the research base [...] the diversification of the curriculum and the development of pedagogy (Xiao and Smith, 2006, Echtner and Jamal, 1997, Tribe, 2005, Tribe and Airey, 2007a, Stergiou et al., 2008, Tribe, 1997, Tribe, 2000, Tribe, 2006b)" Airey (2008a) summarised:

"If the following are indicators of maturity: a community of scholars with the support structures of dedicated journals, other publications and scholarly conferences; a curriculum which is not constrained to a particular territory and about which there is a measure of agreement; an appreciation that teaching is as much about encouraging students to challenge and think as it is about passing on knowledge; a recognition in common with other social sciences that tourism has taken a cultural turn [ ..]; an ability for scholars to be self-critical and aware of the nature of the truths of their work [...]; then [....] tourism has reached a point of maturity"

and Airey (2008b). 
“..existing interests are being joined by new areas of enquiry, by engagement with wider debates and self-criticism, and by a more mature consideration of the role of tourism education. Together these suggest that there may now be a new stage developing; one in which the concerns of tourism are less about justifying or questioning its existence and more about wider debates more akin to of the social sciences generally. Tourism may be moving into a mature stage"

This idea of maturity is also picked up in comments about tourism research. Tribe and Airey (2007b), suggest that far more important than the growth in research, as witnessed by the number of academic journals, is its changing nature in terms of scope, approaches and methods. From a simple focus on what Tribe refers to as extradisciplinary knowledge (1997), an emphasis on the needs of business, and on economics (Jafari and Aaser, 1988) with a positivist stance and quantitative methods, tourism research "has changed almost beyond recognition" (Airey, 2013). As described in the words of Tribe and Airey (2007b): "Many of the gaps in knowledge have been completed and the methodological approaches and research techniques have extended". Tourism research is no longer purely positivist and a reliance on economics has been replaced by a more "eclectic multidisciplinarity" (Tribe and Airey, 2007b). As Tribe (2006a) has described it: "[tourism now] has the characteristics of a fledgling post-modern field of research .... [with] more reflexivity.... [and]..... innovative and radical lines of enquiry" As Airey puts it (2013):

\footnotetext{
"Tourism research now regularly draws upon a wide range of disciplines, it is as likely to take an interpretivist or critical stance as it is to take a positivist one and qualitative methods are just as likely to be found as quantitative. For example, in their study of UK PhD dissertations, Botterill, Gale and Haven (2003) report that "quantitative ... and qualitative ... methods were reported in roughly equal proportions"
} 
and

"In many ways this is another part of the growing maturity of tourism in the academy in that the range, approaches and scope of research in tourism can stand alongside other social sciences .....".

However, Airey (2008b) also tempers this optimistic view with four aspects in which tourism could still be recognised as immature. First he claims that "There is as yet no coherent theoretical framework for tourism as a subject of study; rather its boundaries are still defined by tourism as a field of practice" and secondly that "Knowledge about tourism still draws heavily from other disciplines and consequently remains multidisciplinary with examples of interdisciplinary knowledge creation from within tourism being few and far between". Thirdly, drawing on the work of Meyer and Land (2003), he points to the absence of what they call "threshold knowledge" in tourism; knowledge that "once entered and passed, leads on to new and, for the individual, previously inaccessible ways of thinking" (Airey, 2008b). Finally, he points out the somewhat surprising weakness, given its vocational aspects, in its links with the tourism community more generally, including the tourism industry, public bodies or with the wider community. Here he cites the work of Cooper (2006) and what he refers to as the "hostile knowledge adoption environment" for tourism studies.

Despite these possible weaknesses however, the story so far is nevertheless a remarkable one: of rapid expansion in tourism programmes, across the world; of a growing development and maturity in subject content and in research coverage and approaches; and a greater recognition as a legitimate area of academic endeavour. But at the same time tourism still retains the uncertainties of a new area of academic endeavour. A flavour of these uncertainties is provided in a study about to be published (Airey et al., 2014 (forthcoming)): 
"After forty or more years of development, TH\&E [Tourism Hospitality and Events] education is in an interesting and in some ways contradictory position. It has proved that it can be successful in recruiting students and indeed is now a significant part of some institutions, but on the other hand there is also evidence of programme closures and mergers for lack of student demand (Fidgeon, 2010). It has established a reputation for research with, at least in tourism, some top ranked research journals yet the latest research evaluation exercise in the UK spoke of the long tail of mediocre outputs (Higher Education Funding Council for England, 2012). It has a reasonably good track record for graduate employment but it also shows some very weak links with its related industrial sector (Cooper, 2006). The curriculum has broadly become established (Airey, 2008b) but the debates about the balance between capabilities and knowledge still remain (Dredge et al., 2012)".

These uncertainties set the scene for the current state of tourism education and research in which, above all, a changed environment is increasingly exposing some of its weaknesses.

\section{WHERE ARE WE NOW?}

To a large extent the changes that are shaping current tourism scholarship were already in place during its formative years. The big difference is in the scale and pace of change. A recent study sets out two external changes that are shaping tourism in the academy. The first relates to funding, whereby, as they report, "not only has funding become tighter but, through the introduction of fees, students (and their parents) have increasingly become responsible for funding universities, rather than the taxpayer"(Airey et al., 2014 ). As an example, they point to the fact that the UK government now provides no funding for teaching in universities for the arts, humanities and social sciences (including, of course, tourism). A second external change that they identify is the increased internal 
and external scrutiny of programmes and research activities, the results of which in turn feed the various league tables.

Competition between institutions and rankings of universities, either formal or informal, have been present for as long as tourism in the academy, but the big change here comes from the intensification of competition for students that the change in funding has brought. The result is that universities are now much more acutely aware of the importance of the quality of provision, the attractiveness of their programmes, and their overall reputation, all of which figure in the league tables. It is in this context that institutional managers increasingly make judgements about the activities that they include in their institutions on the extent, above all, to which they attract finance and add to reputation. For finance they look to student recruitment and research funding, for reputation they look to student satisfaction and quality, and to research outputs. For tourism in the academy, based on these metrics, the suggestion is that "institutional leaders would arrive at a critical view when comparing tourism with other fields across a range of different metrics" (Airey et al., 2014 ). In particular they point to weaknesses at many centres in student quality and research outputs as well as difficulties in attracting research income, and they, with others (Fidgeon, 2010), note the recent closure of a number of tourism programmes, presumably because they were not meeting institutional requirements. As a relatively new field of study, while tourism has expanded and developed quickly, and some centres of excellence have emerged, this is clearly not true across the whole academy, leaving what Airey et al. (2014) refer to as a "long tail" of weaker performers. In some ways finance and reputation reflect the dimensions of a key uncertainty that currently still lies at the heart of tourism in the academy and one that is being increasingly exposed by the changing environment. On the one hand tourism needs to attract students, which in part comes from its relationship with the wider world of tourism practice and related employment opportunities 
for students. On the other hand, reputation in the academic community lies more in research and theory. Airey, Dredge and Gross (2014 (forthcoming)) note:

"For TH\&E subject areas that are still establishing themselves in the academy, this provides a key background tension both to prove themselves as academically respectable with obvious implications for an emphasis on research and theory as well as to maintain their apparent links with industry and employment potential. In this lie the ongoing tensions both for the curriculum and for the ways in which academics use their time".

These two external changes, in funding and scrutiny, are taking place alongside a range of other influences and developments to which tourism in the academy is responding. One of these, which indeed provides the whole setting for the competitive environment, is the playing out of neoliberalist policies in the world of universities. The elements of this that are concerned with "the maximization of entrepreneurial freedoms within an institutional framework characterized by private property rights, individual liberty, free markets and free trade" (Harvey, 2006) are of course present in the current competitive environment for higher education. But they also make their presence felt in the development of private funding and private universities and of existing universities seeking additional campuses in other countries to secure their markets. Tourism's ability to attract students means that it figures in many of these initiatives. Neoliberalist thinking, plus the developments in information technology are also drivers for the provision of so-called Massive Open Online Courses (MOOCS) which institutions are using to extend their markets again providing opportunities for tourism in the academy.

While such developments obviously provide opportunities for the development of tourism they also bring uncertainties relating for example to the extent to which tourism is seen simply as a student recruiter operated away from the main campus or outside the main universities. At the same time 
Airey, Dredge and Gross (2014 (forthcoming)) point to the paradox that at the very time when increasing competition might be expected to mean greater differentiation between institutions, the very act of freeing universities has prompted more standardisation, often with the motive to secure at least minimum standards and international recognition. So, for example, the UK developed its Subject Benchmark exercise (Quality Assurance Agency, 2008) to set out the nature and content of programmes, including tourism, an approach that is currently also being pursued in Australia, also for tourism, with their Higher Education Standards Framework (Tertiary Education and Quality Standards Agency, 2012). Similar approaches in tourism, using a standardising template, can be seen at an international level by, for example, the UNWTO and its TEDQUAL initiative (United Nations World Tourism Organization, undated) and THE-ICE (2012). The extent to which these all rest on a similar model, heavily Western oriented, also remains a challenge (Harrison, 2014 (forthcoming)).

Against this, and building on the curriculum work of Tribe (2002), Dredge et al.(2012), in their detailed study of the situation in Australia, point to the extent to which the curriculum space for tourism still remains highly dynamic, responding to both international and external pressures, including, but not confined to, those from the neoliberal environment. They also show that different institutions take somewhat different approaches, and that the curriculum needs to be responsive to different stages of learning. Obviously the details of individual curricula are beyond the scope of this article but drawing on the work of Belhassen and Caton (2011) it is worth noting the stress that they put on the importance of understanding, criticality and reflection being included in the curriculum space. As noted later in this article, this point becomes important for the future development of tourism education. Clearly the curriculum debate is not yet finished in tourism, but unlike the earlier years when the focus was on subject content, it is now much more about stance and philosophy, particularly prompted at present in response to the same neoliberal pressures to see higher education as primarily about preparation for the work-place. As Airey, Dredge and Gross put it (2014 (forthcoming)): "Clearly the curriculum space is the battleground where the various forces 
influencing education need to be resolved".

One aspect of tourism education that appears to compare well with other subjects is in the approaches to learning and teaching. Some evidence for this is provided from Australia by Airey et al. (2014) where, with a national system of awards for teaching innovation, tourism performs as well as other subject areas with tourism academics receiving awards and citations for their work. Generally, field visits play an important and very effective role at many centres as a kind of signature pedagogy for tourism (Portegies and Platenkamp, 2014 (forthcoming), Shulman, 2006) and accounts of innovation in this and in other areas regularly appear in the three journals devoted to learning and teaching in tourism: Journal of Hospitality, Leisure, Sport and Tourism Education; Journal of Hospitality and Tourism Education; Journal of Teaching in Travel and Tourism. A flavour of some of these is captured in the section on curriculum delivery of a recent book on tourism education (Dredge et al., 2014 (forthcoming)-b). Here examples range from the use of project-based studio work, problem-based learning, value-based learning, web 2.0 technologies and work-integrated learning. Further, Cuffy, Tribe and Airey (2012) provide an account of life-long learning for tourism. In other words, pedagogy for tourism is developing well, although at the same time there is a strong recognition of the tension for academics between their work as researchers and their work as teachers and between the need for experimentation and the requirement to conform to regulation, expressed by Wheeller (2005) nearly a decade ago:

"What is needed in today's higher education is an antidote to the straightjacket of restrictive assessment and the ethos of uniform conformity. Something positive, practical but flexible: an environment to give the lecturer room in which to nurture curiosity: one that enables the student to thrive" 
In summary, in many ways tourism in the academy today is in a strong position. Generally, as Airey et al. (2014 ) report, recruitment is holding up and student satisfaction is sound. This is influenced, at least in part, by the attention given to teaching. Also in research terms tourism scholars are developing a good track record of publication in well-ranked journals and having success in securing research grants. However, as they also note, there is still a long tail of weaker performance. The big tension for the next stage of development, both for institutions and for individuals developing their careers in tourism academia is between competition for students, sometimes at centres away from the main campus, and the requirement to perform highly in research performance. Within this there is also the tension between focusing on what Tribe (2002) refers to as the vocational/action versus the more liberal/philosophical aspects of the curriculum. These tensions provide the setting for the next stage in the development of tourism in the academy.

\section{WHERE ARE WE HEADING?}

In their recent article Airey et al. (2014 ) point to some of the challenges that need to be addressed for the future of tourism in the academy. Two of these have particular resonance here. One focuses very much on the immediate performance metrics by which subjects are being judged and which in many ways set up the tensions referred to above. The other takes a much more reflexive view of what subjects like tourism can offer to a world that itself is undergoing massive change and in doing so provides a setting in which the current tensions can at least be ameliorated.

The first challenge is very much about ensuring that the metrics for tourism compare well with other subject areas. In essence this means dealing with is called the "long tail" of poor performance in parts of the tourism academic community. The article by Airey et al. (2014) specifically highlights the recruitment of poor-quality students who struggle to find appropriate employment and the production of inferior research but to these can be added the relatively low success rates in attracting research funding and the weaknesses in the impact of the work of the academy on the 
tourism community more generally. In reality what this approach is about above all is to make sure that performance is good across all metrics which almost inevitably brings with it tension between the attention and rewards that are given to performance in each - particularly between teaching and research. This is obviously an important area for development at least in the short term. In a competitive world no activity can survive for long with inadequate performance and given that the neoliberal environment looks set to continue such action becomes vital if more activities or parts of activities, such as teaching are not to close or to be pushed out of the academy into private training schools.

In contrast with this somewhat short-term and inward looking challenge dealing with current metrics, their second challenge is to highlight the strengths of tourism not captured by current published metrics. Here, foreshadowed by the success in teaching, are some aspects which can make a significant contribution to a postmodern, post-industrial future for tourism education. One of the identifying features of tourism as an area of study is its multi-disciplinary nature. As Tribe (1997) points out it is not set in tight disciplinary boundaries. Rather it draws upon a range of disciplines and as noted earlier draws upon a range of research approaches and methods which in the words of Airey et al. (2014) "make tourism well suited to provide the sort of educational experiences that will meet the challenges of a world of increasing complexity". This is a theme which is also picked up by Dredge, Airey and Gross. (2014 (forthcoming)-a) who make the point that the contribution of tourism in meeting future needs lies not so much in the curriculum itself but in the scope that it offers "of learning the deep, intimate connections between knowledge and daily life, and the capacity to develop critical, mindful and reflexive practice". In other words as a relatively new field of study with imprecise boundaries that span a range of issues as well as employment possibilities, and drawing upon many disciplines it provides rich context for preparation for a post-industrial age, both in terms of research as well as in terms of teaching. This links back to the comments already made about innovative approaches to teaching. Significantly, for tourism these have been supported 
by two specific tourism initiatives: the Tourism Education Futures Initiative (Prebezac, 2012) and the BEST Education Network (BEST Education Network, 2014), both of which have been about positioning education to meet future challenges, in the case of TEFI by promulgating the values of ethics, stewardship, knowledge, professionalism and mutuality (Sheldon et al., 2011).

In a sense, tourism almost has a head start over other subject areas in this second challenge. As Dredge, Airey and Gross (2014 (forthcoming)-a) put it:

"Tourism and hospitality are deeply embedded in contemporary social and economic life and the challenge of understanding and managing these phenomena are bound up in much bigger and broader challenges facing society. TH\&E [Tourism, Hospitality and Events] education therefore provides a lens on our social world, a lens through which processes of change can be identified, understood and critically analysed."

Unlike the metrics driven approach, this emphasises those aspects of tourism where it appears to have an advantage over other areas of study and research, but perhaps more importantly for its position in the academy it takes the characteristics of the subject area as its starting point which has relevance for both teaching and research. In other words it does not put teaching and research in opposition but rather highlights those aspects of the subject that bring them together.

In their consideration of the future, Dredge, Airey and Gross (2014 (forthcoming)-a) suggest that "The extent and speed of change taking place in modern societies is causing transcendental changes in social, economic, ecological and political systems" and that "Higher education is implicated in these changes in profound ways". For tourism education this world of change presents it with a turning point. Almost inevitably some of the focus will be on succeeding against the metrics by which the academy will continue to be measured, no doubt for the foreseeable future. This is in line 
with the comment from Barnett (2013) who notes that "the university's gaze has shrunk to a concern with its fortunes in the immediate world". To this extent to tensions noted above will remain.

On the other hand, and more importantly for tourism in the academy, at the same time, the area of tourism both for research and for teaching is now in a position to provide a rich setting to meet what Barnett (2000) describes as a an age of supercomplexity in which it is not knowledge and skills that are of most importance but "certain kinds of human qualities ........[in which he includes] carefulness, thoughtfulness, humility, criticality, receptiveness, resilience, courage and stillness" (Barnett, 2004). As Austin (2012) puts it "the primary responsibility of those who teach within higher education institutions is to prepare students for an uncertain and changing world" and this calls for what Barnett (2004) refers to as "Mode 3 knowledge" picked up by Austin (2012) as "Mode 3 learning" which "should focus on 'a learning-in-and with-uncertainty". In this world, the somewhat permeable boundaries of tourism knowledge which provide the scope to enter a wide range of human endeavours, problems, challenges and issues and a wide range of disciplines give it almost an inbuilt advantage as a vehicle for research and teaching to meet the needs of an age of supercomplexity

\section{FROM VOCATIONAL TO SUPERCOMPLEXITY}

"Remarkable" was the word used at the start of this article to describe the development of tourism in the academy. At first glance, and indeed in the first section of the article, the "remarkableness" is essentially one of growth in numbers but this quickly gets overtaken by the very rapid transformation of the subject from its clearly vocationally oriented origins to an area of study which matured to take up a position alongside other social sciences. Admittedly there are still plenty of sceptics about the seriousness that tourism offers as an area of study in higher education and for some, tourism remains as an arriviste subject, but it is now widely present in universities across the world and its best, its research and teaching ranks with the best. Admittedly the coming of 
neoliberalism to the university sector brought tensions, especially exposing the extent to which parts of the tourism academy had not yet matured sufficiently. The long tail of poor performance bears witness to this and indeed is very much responsible for setting the agenda for the next stage in this remarkable journey.

There is obviously a need to ensure that the weaknesses in the current provision are dealt with. This relates to both research and teaching, as well to the engagement of the tourism academy with the wider community. But more important than this is the need to ensure that an obsession with metrics, league tables and targets, which seems to have engulfed much of the academic world, does not obscure a longer term route for tourism. In dealing with a current world issue that provides a vehicle for exploring so many different aspects of the challenges facing modern societies - economic, social, environmental, philosophical - and without being bound to particular approaches, tourism is extraordinarily well placed to provide education and research suited to the needs of the stewardship of a complex world. Its success in developing imaginative pedagogy that seems to move toward teaching that, in the words of Dredge, Airey and Gross (2014 (forthcoming)-a) "facilitates critical understandings and creative, innovative thinking about complex problems and to work collaboratively towards addressing them" suggests that at least part of tourism community can see beyond the immediate metrics. This is the key challenge for the tourism academy. Tourism as an area of academic scholarship provides an ideal arena in which to rise to the challenges posed by a supercomplex world and to continue this remarkable journey.

\section{REFERENCES}

AIREY, D. (1979). Tourism Education in the United Kingdom. Tourism Review 34(2): 13-15. AIREY, D. (1995). Tourism Degrees, Past Present and Future, Inaugural Lecture. Nottingham. Nottingham Business School, Nottingham Trent University.

AIREY, D. (2005). Growth and Development. In Airey, D. and Tribe, J. (Eds.) An International Handbook of Tourism Education. Oxford. Elsevier: 13-24.

AIREY, D. (2008a). In Search of a Mature Subject. Journal of Hospitality, Leisure, Sport and Tourism 7(3): 101-103

AIREY, D. (2008b.) Tourism Education: Life Begins at 40. Teoros 27(1): 27-32. 
AIREY, D. (2013). Forty Years of Tourism Education and Research. Poznań University of Economics Review 13(4): 11-19.

AIREY, D., DREDGE, D. and GROSS, M. (2014 forthcoming). Tourism, Hospitality and Events Education in an Age of Change. In Dredge, D., Airey, D. and Gross, M. (Eds.) The Routledge Handbook of Tourism and Hospitality Education. London. Routledge.

AIREY, D. and JOHNSON, S. (1999). The Content of Degree Courses in the UK. Tourism Management 20 (2): $229-235$.

AIREY, D. and NIGHTINGALE, M. (1981). Tourism Occupations, Career Profiles and Knowledge. Annals of Tourism Research 8(1): 52-68.

AIREY, D., TRIBE, J., BENCKENDORFF, P. and XIAO, H. (2014). The Managerial Gaze: The Long Tail of Tourism Education and Research. Journal of Travel Research first published online on February 13, 2014

AITCHISON, C. (2006). The Critical and the Cultural: Explaining the Divergent Paths of Leisure Studies. Leisure Studies 25(4): 417-422.

ATELJEVIC, I., PRITCHARD, A. and MORGAN, N. (2007). The Critical Turn in Tourism Studies. Oxford. Elsevier.

AUSTIN, A. (2012). Challenges and Visions for Higher Education in a Complex World: Commentary on Barnett and Barrie. Higher Education Research and Development 3(1): 57-64.

AYIKORU, M., TRIBE, J. and AIREY, D. (2009). Reading Tourism Education: Neoliberalism Unveiled. Annals of Tourism Research 36(2): 191-221.

BARNETT, R. (2000). Realizing the University in an Age of Supercomplexity. Buckingham. SRHE and Open University Press.

BARNETT, R. (2004). Learning for an Unknown Future. Higher Education Research and Development 23(3): 247-260.

BARNETT, R. (2013). Imagining the University. London. Routledge.

BELHASSEN, Y. and CATON, K. (2011). On the Need for Critical Pedagogy in Tourism Education.

Tourism Management 32(6): 1389-1396.

BEST EDUCATION NETWORK. 2014. BEST Education Network. www.besteducationnetwork.org.

[Accessed 9 September 2014]

BOTTERILL, D. and GALE, T. (2005). Postgraduate and PhD education. In Airey, D. and Tribe, J. (Eds)

An International Handbook of Tourism Education. Oxford. Elsevier: 469-480.

BOTTERILL, D., GALE, T. and HAVEN, C. (2003). A Survey of of Doctoral Theses Accepted by

Universities in the UK and Ireland for Studies Related to Tourism 1990-1999 Tourist Studies 2: 283-

311.

COOPER, C. (2006). Knowledge Management and Tourism. Annals of Tourism Research 33(1): 47-64. COUNCIL FOR NATIONAL ACADEMIC AWARDS (1993). Review of Tourism Studies Degree Courses.

London. Council for National Academic Awards.

CUFFY, V., TRIBE, J. and AIREY, D. (2012). Lifelong Learning for Tourism. Annals of Tourism Research 39(3): 1402-1424.

DEPARTMENT OF EDUCATION, TRAINING AND YOUTH AFFAIRS (2001). Higher Education Students

Time Series Tables. Canberra. Commonwealth of Australia.

DEPARTMENT OF INDUSTRY, INNOVATION, SCIENCE, RESEARCH AND TERTIARY EDUCATION. (2012).

Higher Education Statistics

http://www.innovation.gov.au/HigherEducation/HigherEducationStatistics [Accessed 1 December 2012].

DREDGE, D., AIREY, D. and GROSS, M. (2014 forthcoming a). Creating the Future: Tourism, Hospitality and Events Education in a Post-Industrial, Post-Disciplinary World. In Dredge, D., Airey, D. and Gross, M. (Eds) The Routledge Handbook of Tourism and Hospitality Education. London. Routledge.

DREDGE, D., AIREY, D. and GROSS, M. (Eds) (2014 forthcoming b). The Routledge Handbook of Tourism and Hsoptiality Education. London. Routledge. 
DREDGE, D., BENCKENDORFF, P., DAY, M., GROSS, M., WALO, M., WEEKS, P. and WHITELAW, P. (2012). The Philosophic Practitioner and the Curriculum Space. Annals of Tourism Research 39(4): 2154-2176.

ECHTNER, C. M. and JAMAL, T. B. (1997). The Disciplinary Dilemma of Tourism Studies. Annals of Tourism Research, 24(4): 868-883.

FIDGEON, P. (2010). Tourism Education and Curriculum Design: A Time for Consolidation and Review? Tourism Management 31(6): 699-722.

HARRISON, D. (2014 forthcoming). Educating Tourism Students in the South Pacific: Changing Cultures, Changing Economies. In Dredge, D., Airey, D. and Gross, M. (Eds) Routledge Handbook of Tourism and Hospitality Education. London. Routledge.

HARVEY, D. (2006). Neoliberalism as Creative Destruction. Geografiska Annaler, Series B: Human Geography 88(2): 145-158.

HIGHER EDUCATION FUNDING COUNCIL FOR ENGLAND (2012). REF2014 Assessment Framework and Guidance on Submissions. Bristol. Higher Education Funding Council for England.

JAFARI, J. (2001). The Scientification of Tourism. In Smith, V. L. and Brent, M. (Eds) Hosts and Guests Revisited: Tourism Issues of the 21st Century. New York. Cognizant Communications Corporation: 2841.

JAFARI, J. and AASER, D. (1988). Tourism as the Subject of Doctoral Dissertations. Annals of Tourism Research 15(3): 407-429.

MEDLIK, S. (1965). Higher Education and Research in Tourism in Western Europe. London. University of Surrey.

MEYER, J. H. F. and LAND, R. (2003). Threshold Concepts and Troublesome Knowledge - Linkages to Ways of Thinking and Practising. In Rust, C. (Ed.) Improving Student Learning - Ten Years On. Oxford. OCSLD.

PORTEGIES, A. and PLATENKAMP, V. (2014 forthcoming). Embedded Research: A Pragmatic Design for Contextual Learning - From Fieldtrip to Fieldwork to Field Research in Australasia. In Dredge, D., Airey, D. and Gross, M. (Eds) The Routledge Handbook of Tourism and Hospitality Education. London. Routledge.

PREBEZAC, D. (2012). Guest Editor's Note: Special Issue, Tourism Education Futures Initiative (TEFI) Collection. Teaching in Travel and Tourism 12(1): 1-2.

QUALITY ASSURANCE AGENCY (2000). Hospitality, Leisure, Sport and Tourism, Subject Benchmark. Gloucester. Quality Assurance Agency for Higher Education.

QUALITY ASSURANCE AGENCY (2008). Subject Benchmark Statement, Hospitality, Leisure, Sport and Tourism. Gloucester. Quality Assurance Agency for Higher Education.

SHELDON, P., FESENMAIER, D. and TRIBE, J. (2011). The Tourism Education Futures Initiative (TEFI) Activating Change in Tourism Education. Journal of Teaching in Travel \& Tourism 11(1): 2-23.

SHULMAN, L. S. (2006). Signature Pedagogies in the Professions. Daedalus 134(3): 52-59.

STERGIOU, D., AIREY, D. \& RILEY, M. (2008). Making Sense of Tourism Teaching. Annals of Tourism Research 35(3): 631-649.

TERTIARY EDUCATION AND QUALITY STANDARDS AGENCY (2012). Higher Education Standards Framework. Canberra. Australian Government. http://www.teqsa.gov.au/higher-educationstandards-framework [Accessed 2 April 2014].

THE-ICE. (2012). International Centre of Excellence in Tourism and Hospitality Education (THE-ICE). http://www.the-ice.org/about-us/who-we-are [Accessed 12 September 2012].

TRIBE, J. (1997). The Indiscipline of Tourism. Annals of Tourism Research 24(3): 628-657. TRIBE, J. (2000). Indisciplined and Unsubstantiated. Annals of Tourism Research 27(3): 809-813. TRIBE, J. (2002). The Philosophic Practitioner. Annals of Tourism Research 29(2): 338-357. TRIBE, J. (2005). Tourism, Knowledge and the Curriculum. In Airey, D. and Tribe, J. (Eds) An International Handbook of Tourism Education. Oxford. Elsevier: 47-60.

TRIBE, J. (2006a). Towards New Tourism Research. Tourism Recreation Research 30(2): 1-3. TRIBE, J. (2006b). The Truth about Tourism. Annals of Tourism Research, 33(2): 360-381. 
TRIBE, J. and AIREY, D. (2007a). Developments in Tourism Research, Oxford, Elsevier.

TRIBE, J. and AIREY, D. (2007b). A Review of Tourism Research. In Tribe, J. \& Airey, D. (Eds)

Developments in Tourism Research. Oxford. Elsevier: 3-16.

UNITED NATIONS WORLD TOURISM ORGANIZATION (2006). Tourism Market Trends 2006 edition.

Madrid. United Nations World Tourism Organization.

UNITED NATIONS WORLD TOURISM ORGANIZATION (undated). Tedqual. Andorra. Themis

Foundation and United Nations World Tourism Organization.

WALMSLEY, A. (2012). Tourism Intelligence Monitor: ATHE Report on Tourism Higher Education in the UK 2012. Brighton. Association for Tourism in Higher Education.

WHEELLER, B. (2005). Issues in Teaching and Learning. In Airey, D. and Tribe, J. (Eds) An International Handbook of Tourism Education. Oxford. Elsevier: 309-318.

XIAO, H. (2000). China's Tourism Education into the 21st Century. Annals of Tourism Research 27(4): 1052-1055.

XIAO, H. and SMITH, S. (2006). The Making of Tourism Research: Insights from a Social Sciences Journal. Annals of Tourism Research 33(2): 490-507.

YANG, J. and SONG, H. (2011). Tourism Education Programmes in Mainland China. AngloHigher, The Magazine of Global English Speaking Higher Education. Coventry, University of Warwick. Panethnic Limited. 